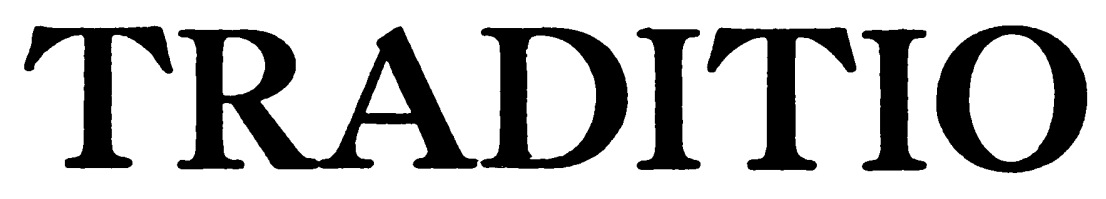

STUDIES IN ANCIENT AND MEDIEVAL HISTORY, THOUGHT AND RELIGION

Editors

STEPHAN KUTTNER ANSELM STRITTMATTER

EDWIN A. QUAIN BERNARD M. PEEBLES

ROBERT E. MCNALLY

VOLUME XX

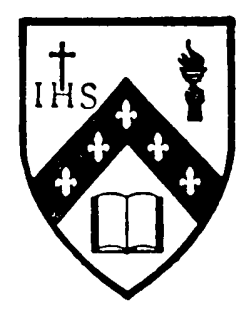

FORDHAM UNIVERSITY PRESS

NEW YoRK

1964 
Published annually at Fordham University Press, New York 58, N. Y. All correspondence concerning business matters should be addressed to the Director of the Press. Subscription $\$ 8.00$

Single Copies $\$ 9.00$

Correspondence with regard io articles should be sent to one of the Editors :

Stephan KuttNer, J.U.D.

Yale University

Niw Haven, Conn.

Edwin A. Quain, S.J.

Fordham Lniversity

New York 58, N. Y
Dom Anselm Strittmatter, O.S.B

St. Anselm's Abbey

Washington 17, D. C.

Bennard M. Peebles, Ph.D.

The Catholic Lniversity of America Washinglon 17, D. C.

\section{Robert E. McNally, S.J. \\ Woodstock College \\ Woodstock, Md.}

Printed at

IMPRIMERIE CULTURA

Wetteren, Belgium

European clients will kindly address all subscriptions or single orders to Imprimerie Cultura, 22 rue Hoender, Wetteren (Belgium). 
IN MEMORIAM

\title{
ERNESTI KANTOROWICZ
}

\author{
VIRI EXIMII \\ QVI ERVDITIONE PARITER ET HVMANITATE \\ CIS OCEANVM ET VLTRA \\ ARTEM HISTORICAM INSIGNITER AVXIT
}




\section{CONTENTS}

ARTICLES

Saint John Chrysostom, 'De fato et providentia': A Study of its Authenticity . . . . . . . Thomas P. Halton

The Public Assembly in the Time of Louis the Pious

Joel T. Rosenthal

Count Gerald of Aurillac and Feudalism in South Central France in the Early Tenth Century . . Archibald R. Lewis

Sulcard of Westminster: 'Prologus de construccione Westmonasterii' Bernhard W Scholz

The Cathedral School of Reims in the Time of Master Alberic, $1118-1136$ • . . . . . . John R. Williams

A New Eyewitness Account of the Fourth Lateran Council

Stephan Kuttner and Antonio García y García

The Theory of Papal Monarchy in the Thirteenth Century: The Contribution of the Canonists - J. A. WATt

The Codicil of Cardinal Comes of Casate and the Libraries of ThirteenthCentury Cardinals - Richard Mather

Temporal and Spiritual Regalia during the Reigns of St. Louis and Philip II Gerard J. Campbell, S.J. 351

Godfrey of Fontaines and the Real Distinction between Essence and Existence - John F. Wippel 385

\section{MISCELLANY}

Les manuscrits de Montfaucon et l'édition de S. Jean Chrysostome F. J. Leroy, S.J. 411

Étude sur le manuscrits d'un texte de Jean Chrysostome

A.-M. Malingrey 418

Survey of Recent Work on St. Maximus the Confessor

Dom Polycarp Sherwood 428

The Carolingian Military Frontier in Italy Katherine F. Drew 437 The Oldest Text of the 'Constitutum Constantini' Schafer Williams 448

The Origins of Numerical Symbolism and Numerical Patterns in Medieval German Literature - Michael S. Batts 462 


\section{Bibliographical Survey}

Ecumenism and Patristic Scholarship: A Survey of Recent Work

Herbert Musurillo, S.J. 473

\section{INSTITUTE OF MEDIEVAL CANON LAW BULLETIN FOR 1964}

Annual Report

Les 'Questiones' des canonistes (IV)

491

Hostiensis and Some Embrun Provincial Councils Richard KaY 503

Select Bibliography 1963-1964

- 513

Microfilms and Photostats Acquired in 1964

Photostats from the Holtzmann Estate 524

Catalogue of offprints: Volumes I through XX 


\section{ABBREVIATIONS}

The following sigla are used without further explanation:

\begin{tabular}{|c|c|}
\hline $\mathrm{AH}$ & Analecta hymnica medii aevi \\
\hline AS & Acta sanctorum \\
\hline CAH & Cambridge Ancient History \\
\hline CCL & Corpus Christianorum: Series latina \\
\hline CIL & Corpus inscriptionum latinarum \\
\hline $\mathrm{CMH}$ & Cambridge Mediaeval History \\
\hline $\mathrm{CSCO}$ & Corpus scriptorum christianorum orientalium \\
\hline CSEL & Corpus scriptorum ecclesiasticorum latinorum \\
\hline DACL & Dictionnaire d'archéologie chrétienne et de liturgie \\
\hline $\mathrm{DDC}$ & Dictionnaire de droit canonique \\
\hline DHGE & Dictionnaire d'histoire et de géographie ecclésiastiques \\
\hline DS & Daremberg-Saglio, Dictionnaire des antiquités grecques et romaines \\
\hline DThC & Dictionnaire de théologie catholique \\
\hline Du Cange & Du Cange, Favre, Henschel, Glossarium mediae et infimae latinitatis \\
\hline EETS & Early English Text Society \\
\hline GCS & Die griechischen christlichen Schriftsteller der ersten drei Jahrhunderte \\
\hline HBS & Henry Bradshaw Society \\
\hline IG & Inscriptiones graecae \\
\hline ILS & Dessau, Inscriptiones latinae selectae \\
\hline JL & Jaffé, Regesta pontificum romanorum \\
\hline JK & S. Loewenfeld (JL: an. 882-1198), F. Kaltenbrunner (JK: an. ?-590), \\
\hline $\mathrm{JE}$ & P. Ewald (JE: an. 590-882) \\
\hline LThK & Lexikon für Theologie und Kirche \\
\hline Mansi & Mansi, Sacrorum conciliorum nova et amplissima collectio \\
\hline MGH & Monumenta Germaniae historica \\
\hline $\mathrm{PG}$ & Migne, Patrologia graeca \\
\hline PL & Migne, Patrologia latina \\
\hline PO & Patrologia orientalis \\
\hline Potthast & Potthast, Regesta pontificum romanorum \\
\hline $\mathrm{RE}$ & $\begin{array}{l}\text { Pauly, Wissowa, Kroll, Real-Encyclopädie der klassischen Altertums- } \\
\text { wissenschaft }\end{array}$ \\
\hline $\mathrm{RIS}^{2}$ & $\begin{array}{c}\text { Muratori, Rerum italicarum scriptores: Raccolta degli storici italiani, } \\
\text { nuova ed. }\end{array}$ \\
\hline SIG & Dittenberger, Sylloge inscriptionum graecarum \\
\hline ThLL & Thesaurus linguae latinae \\
\hline TU & Texte und Untersuchungen zur Geschichte der altchristlichen Literatur. \\
\hline
\end{tabular}

For serial publications of the great academies:

Abh. Akad. [followed by name of city, e.g. Berlin, Munich, etc.] = Abhandlungen der [preussischen, bayerischen, etc.] Akademie der Wissenschaften, philosophisch-historische Klasse

Similarly for Mémoires, Memorie, Proceedings, Rendiconti, Sitzungsberichte, etc., the abridged form is always understood as referring to the series covering philosophy and the humanities where several classes or sections exist in a single academy. E.g.:

Mém. Acad. Inscr.

Proc. Brit. Acad.

Rendic. Accad. Lincei
Rendic. Istit. Lombardo

Sb. Akad. Vienna 